\title{
THE WORK OF CREATION: IMAGE, IDOLATRY, AND JEW ISH DISCOURSE IN THEOLOGY AND THE ARTS
}

\author{
Alana M. Vincent*
}

\begin{abstract}
The Second Commandment, prohibiting both the worship and manufacture of graven images, is often employed as a mechanism for explaining a perceived absence of Jewish participation in the visual arts, in spite of a well recorded history of Jewish participation in the manufacture of graven images which are typically classed as craft objects. This article aims to introduce to theology the scepticism towards hierarchical distinctions between art and craft which is already familiar in the world of art theory, and by so doing prompt a dislocation of theological reflection on works of art from the point of visual engagement to the point of manufacture. It suggests that attentiveness to Jewish discourses about material production opens up interesting and potentially generative possibilities for work in theology and the arts beyond the consideration of specifically Jewish art.
\end{abstract}

My higher education began, inauspiciously, amid the dust and noise of a cinderblock warehouse with a corrugated metal roof, hot in summer and bitterly cold in winter, unless the foundry was running (and, for the most part, the foundry only ran during the summer). This was the sculpture department at what was then a small, and is now a defunct, school of art in the south-eastern United States. Under the watchful eye of instructors with names like Cohen and Emmanuel, I learned to shape wood and cast bronze, to form figures from clay, to carve them from stone.

We were never concerned about the possibility of idolatry.

What we were concerned with, deeply concerned with, was the possibility that what we were creating was not really art. We worried that it was either too decorative, or else too functional. That it might accidentally match someone's sofa. That it might, worst of all, be mistaken for craft.

\footnotetext{
* Department of Theology \& Religious Studies, University of Chester, Parkgate Road, Chester. Email: a.vincent@chester.ac.uk
} 
At approximately the same time that I was completing my studio training, Grace M. Jantzen published a review article, 'Beauty for Ashes: Notes on the Displacement of Beauty', 1 covering a number of then-recent volumes, several of which have since become classics, in which she identifies and critiques the tendency of theological writing on aesthetics and art to assume the primacy of Christian doctrine as the measure of artistic value, and argues the need for:

a theology not based on the standard formulations of doctrine and practice of the christendom of modernity but on a divine horizon in which alterities of gender, economics, and ethnicity are allowed to destabilize our comfortable assumptions, and in which the ethical and aesthetic considerations generated by these alterities shape the theology as surely as they are shaped by it. ${ }^{2}$

Jantzen's early death prevented her own vision of such a project from reaching fruition, and very little of the work done since that time has taken her prescription seriously; ${ }^{3}$ this article represents a very preliminary attempt at a response, an engagement with alterity that points towards a constructive reshaping of theology via careful consideration of the religious assumptions which underlie hierarchies of aesthetic value.

The history of Jewish material production, prior to the nineteenth century, appears to be predominantly a history of precisely the sort of decorative or functional objects which my classmates and I were so keen to avoid. Harold Rosenberg made this point explicitly in a 1966 talk given at the New York Jewish Museum on the subject of 'Jewish Art': 'In short, a Jewish handicraft exists and a handicraft tradition. This is what scholars usually accept as Jewish art. ${ }^{44}$ From the nineteenth century onwards, scholars who perceive Judaism as a religious system, as opposed to an ethnicity, have been prone to narrate a history of exceptionalism, if not outright apostasy, when describing material production by Jews which does not fit within the category of craft. ${ }^{5}$ Leaving aside the art historical works which avoid engaging with religion and instead attempt to trace a common 'Jewish experience', ${ }^{6}$ there remain few, if any, discussions of Jewish art which fail to make reference to the commandment against graven images, and indeed most treat it as the natural starting point: the first thing which we must all understand about Jewish art is that it may not, strictly speaking, actually exist. ${ }^{7}$ Clearly, the present article is no exception to this rule. I hope, however, that it may lay the ground for future discussions of art and theology which are inclusive of Jewish contributions evaluated on their own merits, rather than read through a hermeneutics of contrast - the tendency to treat Judaism as an inversion of Christianity, by virtue of the assumption that it is 'a tradition of law without grace'-which has long characterised Christian theological use of post-Biblical Jewish sources. ${ }^{8}$ What I am proposing is subtly different from the use of Jewish texts to buttress 
some existing doctrine of orthodox Christianity: I am not suggesting that Jewish sources be read as supportive or confirmatory of Christian universalism, but rather that they be taken precisely as challenges to that universalism, as able to prompt lines of inquiry that would not be readily approachable by the normal routes of systematic theology. ${ }^{9}$ I am aiming not at syncretism, but pluralism.

In this article, I will argue that anxiety over what art is, or, more properly, over what is and is not art, is the fraternal twin to the anxiety that theology (and particularly Jewish theology) suffers over questions of image and idolatry. Moreover, I would like to argue that these twin anxieties over which sorts of images are permissible, or even desirable, may themselves be read as mutually constructive of each other, and it behoves scholars of theology and the arts to attend to the discourse of artistic value as also a discourse of religious difference. My intention is neither to dismantle the existing art historical consensus on the range of Jewish material production (although I will indicate points at which others have opened that consensus up to questioning) nor to erect a counter-narrative in its place, but rather to offer, particularly to theologians of the arts, some suggestions of where the broad range of Jewish thought-from the Hebrew Bible to modern secular philosophy-extends an understanding of the work of art that is considerably more complex than recourse to the Biblical text would indicate. My ultimate aim is to introduce to theology the scepticism towards hierarchical distinctions between art and craft which is already familiar in the world of art theory, and by so doing prompt a dislocation of theological reflection on works of art from the point of visual engagement to the point of manufacture. I suggest, in short, that attentiveness to Jewish discourses about material production opens up interesting and potentially generative possibilities for work in theology and the arts beyond the consideration of specifically Jewish art.

\section{BEGINNING}

Let me begin, as most studies of Jewish art do, with the Bible-but instead of the nineteenth chapter of Exodus, I want to focus first on the first chapter of the book of Genesis. Here, the creator creates, and, as Melissa Raphael is at pains to point out in her most recent book, the creator beholds creation, and sees that it is good. ${ }^{10}$ Susan Handelman notes that the Biblical creation myth relates a distinctively Jewish form of generativity:

In popular Greek religion, the gods were anthropomorphically envisioned as producers of things after the analogy of animal procreation. The divinity begot other gods. Jewish thought was strikingly different. The God of Scripture was a creator of the world, not as begetter but as artisan (as in the famous midrash, 'God 
looked into the Torah and created the world,' after the manner of an architect). A begetter begets something out of his own essence, like himself; whereas an artisan creates something different from and unlike himself. ${ }^{11}$

The creator creates; the earth not begotten, but made. The creator beholds creation, the entirety of which, both action and result, is a visual spectacle.

It is, however, no image - at least, not in the sense of the English word, which derives from the Latin imago and refers to a likeness, or imitation, of another thing. ${ }^{12} \mathrm{No}$, the introduction of images into the visual field must wait until the sixth day, the twenty-seventh verse, when the creator creates humanity:

\section{ויברא אלהים את־האדם בּצלמו בּצלם אלהים בּרא אתו זכר ונקבה בּרא אתם}

And God filled humankind with God's own Image (tselem); God created them male and female, filling both with the Image of God. ${ }^{13}$

This verse is the source text for what contemporary Jewish theologians, such as Arthur Green, ${ }^{14}$ Melissa Raphael, and David Blumenthal, call the 'theology of image'. The notion that humanity bears the Image of God means that humanity becomes a source of theological understanding: the attributes of God are reflected in humanity; a statement that can be made about humanity also applies to God. ${ }^{15}$ Much as art schools in years past filled their studios with plaster casts of great works for students to study, we can learn about the original by examining the imitation; we see the Other reflected in our own faces. ${ }^{16}$ It is significant to note that while Blumenthal is firmly focused on seeking an understanding of God couched in human terms, he also posits that most statements that might be made about God can also apply to humanity, that the attribute of holiness is an essential part of the Theology of Imagehumans partake of, and are able to understand themselves through, Godliness. ${ }^{17}$ This move also has scriptural roots, of course-for example, the commandments in Leviticus that Israel is to be holy as God is holy. ${ }^{18}$ But the theology of Image is not simply a Jewish gloss on Platonism; humanity is not a pale copy of God. Rather, '[h] umanity, in its individual and collective existence, is created in God's image and hence struggles, together with God, to live the depth of that image'. ${ }^{19}$ The Theology of Image reveals God and humanity engaged in mutual regard, each learning how to be themselves through encounter with the other. ${ }^{20}$

The creator creates a self-image, but even this very first act of imagemaking carries traces of anxiety. By the twenty-second verse of the third chapter of Genesis, the creator decides that the creation has become too close an imitation, has transgressed not only through disobedience-eating the fruit of the forbidden tree-but through a blurring of the boundary 
between creator and creation: 'Behold, the creature of earth has become like us. ${ }^{21}$ The creatures' expulsion from Eden immediately follows this observation - and several of the more common English translations link verses 22 and 23 with the insertion of the word 'so' or 'therefore', heightening the sense of cause and effect that is implied in the Hebrew. ${ }^{22}$

It is this anxiety on which I wish to focus, this hint that the commandment of Exodus 20:4 and Deuteronomy 5:8 might have in the first instance less to do with making images - imitations of creation - and more to do with being images, imitating too closely the actions of the one great Creator, blurring the boundaries between the human self and the divine Other. Humanity reflects the divine image, but is not itself divine, and covenantal limitations are placed upon human activities which risk imitating divinity too closely. This is the dark side of the Theology of Image. Viewing the covenant - and, in this case, the second commandment in particular - through the lens of relationality, of imitation and restriction, permits us to refocus discourse about art-making, moving from debates over product-figurative or non-figurative, idolatrous or reverent- to discussions of praxis. ${ }^{23}$ Idolatry, as a disruption of the relationship between human and divine, is then not so much in the eye of the beholder as it is in the hand of the maker.

\section{MANUFACTURE}

In short, I propose that the second commandment might be seen, through contemporary eyes, not as a prohibition of images in general, but as a very particular prohibition of art. I say 'through contemporary eyes' because I am emphatically not making any claims about the historical meaning of the Biblical text. To do so would be nonsense, as the idea of art which I am working with is of a relatively recent vintage, being at most approximately five hundred years old. ${ }^{24}$ The word itself is far older, being, like image, of Latin derivation, and there is thus ample room for confusion over the meaning of classical and medieval sources, in which ars or art is used primarily in reference to technical skill - a phenomenon which contemporary English usage would designate with the Teutonically-derived word 'craft' - which originally, and in most other language still carries connotations of strength, power, or mastery. $^{25}$ The power or mastery signalled by the term 'craft' was more often technical (or mental) than a matter of sheer physical strength, and the word was, for several centuries, roughly synonymous with 'art'. The art/craft divide dates to approximately the late seventeenth century, when 'art' began to take on connotations of creativity and imagination; over time, this linguistic differentiation came to signal a sharp conceptual divide, representing two distinct modes of production. ${ }^{26}$ 
The treatment of art and craft as distinct modes of production has, under some schemata, been focused almost entirely on product rather than process, form rather than function. Students today are taught that the current division derives from the Renaissance, in which the equivalent distinction was between 'art' and 'fine art', the latter comprising painting, sculpture, and architecture, and the former every other sort of material production. Paul Greenhalgh rightly questions the historical accuracy of this neat division, noting that 'fine art as such continued well after the sixteenth century to routinely include other disciplines such as poetry, music, rhetoric and eloquence, and that the Renaissance groupings were not in any way systematic'. ${ }^{27}$ Even in the more complicated picture drawn by Greenhalgh, one finds a vague sense that art or fine art is distinguished from its lesser cousin, craft (or art that is not fine art) by a certain superfluity: shelter is necessary, architecture, in the sense of space designed with aesthetic concerns in mind, is not, nor are paintings or sculptures meant to ornament that space; communication and information transfer are necessary, eloquence, rhetoric, and musicality are not. I will defer from considering the questions raised by including works of literature or music in the discussion of art, not because I believe that they ought not qualify as such-indeed, it should be clear by end of this article that most of what I have to say applies to these modes of production as well-but because at this point the distinction I am attempting to illuminate, and its historical development, is better understood when restricted to the plastic arts. In its simplest form, the product distinction does not engage with even the low level of functionalism apparent in the idea of superfluity; rather, an art object is simply an object which takes a form recognisable as art-which is to say, sculpture or painting - and a craft object is an object which takes a form recognisable as craft-'pottery, jewellery-making, basketry, weaving, etc' ${ }^{28}$

However, function has become increasingly important to the definition of art. Thus, the philosopher R.G. Collingwood formulated a still-influential theory of art that rested primarily on the idea of art as a form of production which does not adhere to the criteria of craft production. ${ }^{29}$ This is not to say that art does not involve many of the same processes as craft, but the principle of superfluity comes into play. Art transcends craft; it may utilise similar materials and methods of production, but the response it elicits from both the artist and the viewer is incommensurate with its material origins. Art, as it is now understood, is a unique product of the imagination of its creator, a work of the mind as much if not more so than the hands; while a work of art might involve images, the goal is not to imitate, but to make something wholly new: creatio ex nihilo, or, if that seems too much of an exaggeration, then creatio ex as close to nihilo as is humanly possible. Craft, by contrast, is understood to be formulaic, following a set plan in order to produce an object whose characteristics are predetermined. This opposition is illuminated in T.R. Martland's 
article, 'Art and Craft: The Distinction', which, while outdated in its diction, is a fair summary of the reasoning that leads to a pejorative use of the word craft:

They are craftsmen all, Gepettos or Kings of Cyprus, who by their actions intend to bring to life their own favourite Pinocchio or their own favourite Pygmalion. Along with Faust in Auerbach's cellar they all intend to evoke old experiences rather than move on to new experiences. They all want the security of repossessing the past, to release or defend again what they already experience. This means none of them have room in their work for what the work itself might add. None of them want the obligation to relate to the open future. None of them have the intention to save themselves for what Delacroix calls 'a certain abandon later on, for discoveries made as the work advances'. 30

Especially interesting for my purposes are the examples of craft that Martland selects: Pinocchio, Pygmalion. ${ }^{31}$ According to Martland, the desire to imbue the object with life and then dwell with the companion of one's own creation is a flight from originality, from the risk and unpredictability entailed by relationship with something outside of one's own sphere of control. In striving to bring the work to life, he suggests, Gepetto and Pygmalion paradoxically rob the work of the capability to transform itself or its creator. They seek to avoid a lengthy engagement with work qua work. By transforming the object they manufacture into something other than what it is, by using the process of manufacture as a means rather than an end in itself, they create only an image of themselves, of the familiar. They bring the work into their world, rather than entering into the world of the work. In so doing, they control everything, and risk nothing. What Gepetto and Pygmalion seek to create, according to Martland, is image, not art. I will return to the implications of this image-making in terms of the second commandment at the end of this article; for now, the suggestion that such creation may actually be less religiously problematic than the mutually transformative engagement with art which Martland endorses must suffice.

This hierarchical distinction between art and craft, drawn so explicitly in the world of aesthetics and art theory, has enabled the tacit dismissal of craft as a mode of legitimate expression worthy of serious study in disciplines such as theology. At the same time, the categorisation of Jewish material production as craft - and of Jewish art as the product of assimilation-has ensured that work on art and theology, which until quite recently has been an exclusively Christian concern, begins and ends its consideration of Jewish art and art theory with the second commandment. The main exceptions to this circumstance are twentieth-century secular Jewish thinkers who have been caught up in the more general turn to continental philosophy, and who are therefore 
read as philosophers rather than as Jews. ${ }^{32}$ Two such thinkers, Walter Benjamin and Hannah Arendt, offer theories of art which, read alongside the Theology of Image that has been developed by post-holocaust theologians, point the way towards a potentially positive Jewish contribution to a theology of art. Both thinkers wrote loosely in response to Marxist materialism, though Arendt's position involved considerably more critique than Benjamin's; both write from a secular Jewish standpoint, although certain traces of what might be characterised as classically Jewish attitudes towards art and images are discernible in their thought. The combination of these two shared attitudes leads to a number of shared concerns in both articles, most notable of which is a focus on the work of art as an object-specifically, an object of significance which transcends its place in the system of commercial exchange, an object possessed of irreducible-and irreproducible-qualities which derive from its genesis as a work of human imagination.

\section{REPRODUCTION}

An art object, for Benjamin, has a very specific set of functions, and his article 'The Work of Art in the Age of Mechanical Reproduction' is primarily concerned with the degree to which the advent of film technology with its inbuilt reproductive capabilities has shifted the function, and therefore the nature, of the art object away from cultic and towards political significance. ${ }^{33}$ As befits the article's historical focus, the actual criteria for determining whether an object qualifies as art are implicit and unstable - 'art' for Benjamin is whatever has been called art in the past, or is being treated as art in the present. However, there remain in his discourse about what is lost or dislocated in the process of reproduction, and more so in the transference of artistic production to media in which there is no 'original', ideas which are of value for my discussion.

Benjamin suggests that the original function of all art was religious. Although he is, in this article, more concerned with religion as a social phenomenon than a theological one, he nevertheless draws an implicit historical connection between the aura of the un-reproduced art object and its historical status as a vehicle of revelation in a cultic context. ${ }^{34} \mathrm{He}$ goes so far as to suggest that the increased emphasis on art for art's sake - the beginning of the suspicion of craft that came to pervade my own training-began in the nineteenth century as a way of retaining the ritualistic, quasi-religious significance of art in the face of the advent of photography; he glancingly proposes that this emphasis in itself constitutes a theology of art, though the concept does not receive any further development in this particular article. ${ }^{35}$

Historically, Benjamin's idea of aura derives from the cultic function of objects, such as Greek and Roman statues, that came to be considered by 
later generations as archetypical works of art. The motions of pilgrimage, the long journey undertaken in hope of standing, however briefly, in the presence of the deity that the statue represents, inform the way viewers respond to later works of art. The object's function as mediator between the viewer and the deity morphed into a mediation between the viewer and the object's human creator, the artist, but the necessity of presence, the object's 'unique existence at the place where it happens to be' remained. ${ }^{36}$ Charles W. Haxthausen notes that the emphasis on the physicality of an object represents an evolution in Benjamin's concept of the aura between this article and his previous work, in which ' $\mathrm{t}$ ] he aura... was located in the image, not in any unique physical object'. 37 The shift of authority from image to object, from abstract to concrete, is quite significant. The increased importance of physicality, and decreased importance of concept, permitted Benjamin to construct his now famous narrative of the demise of the aura, the decentralisation of authority and the rise of the proletariat. ${ }^{38}$ Only when the aura resides in a physical object, rather than in the idea of that object, can the object act as the locus of authority, as in the case of the cultic statue.

Benjamin constructs the aura as a difficult-to-grasp quality possessed by art objects which derives from and from which is derived their status as art. It is difficult, as a theologian, to avoid making a leap from this quality to the idea of the soul, that equally difficult-to-grasp quality which renders humanity human. An art object's aura derives in no small part from its conditions of manufacture, and it is perhaps not overstating the case to suggest-as other theorists of art have done-that it is the artist who imbues their work with its quality of being art, in a manner not dissimilar to the Creator breathing the quality of being human into the creature in the second chapter of Genesis. Reproduction, which Benjamin treats as a process by which the authority of the original is undermined, can then be understood as a dilution of the presence of the $\mathrm{C}$ /creator in the I/image. All art borrows from its maker some of the substance of that maker's own being-its life, its tselem. All art is reproduction.

\section{REIFICATION}

In contrast to Benjamin, Arendt offers a highly developed technical definition of art, without assigning any function at all to art objects. In fact, to Arendt, the art object is specifically that object which serves no discernible purpose, which 'must be removed carefully from the whole context of ordinary use objects to obtain its proper place in the world'. ${ }^{39}$ In transcending use, the art object also transcends the cycle of production and decay which mark all other 
spheres of material production. The art object does not, however, transcend the realm of commercial exchange. Rather, to Arendt, art is defined by commercial value which in no way rests on use value.

Benjamin's idea of the aura shifted over time, from a property of ideas to a property of objects. Arendt encapsulates this shift and theorises it as the means by which art comes to exist: the process of 'reification', in which pure thought is rendered tangible. She writes:

The thought process by itself no more produces and fabricates tangible things, such as books, paintings, sculptures, or compositions, than usage by itself produces and fabricates houses and furniture. The reification which occurs in writing something down, painting an image, modeling a figure, or composing a melody is of course related to the thought which preceded it, but what actually makes the thought a reality and fabricates things of thought is the same workmanship which, through the primordial instrument of human hands, builds the other durable things of human artifice. ${ }^{40}$

Reification is the process in which abstract thoughts coalesce, solidify, become able to be picked up and moved around and bought and sold; it enables them to endure long after the people who thought them have ended their brief sojourn on the earth. It is, in the case of art works ... more than mere transformation; it is transfiguration, a veritable metamorphosis. ${ }^{41}$ It is the thing which makes possible the transfiguration of the space humanity inhabits from the earth to what Arendt calls 'the world', a space capable of containing human action rather than mere animal labour. ${ }^{42}$

The hierarchy of values which Arendt constructs in the pages of The Human Condition is admittedly somewhat uncomfortable, as her student, Richard Sennett, has noted. ${ }^{43}$ Arendt identifies three distinct fields of human endeavour-labour, work, and action-and places the highest value on those things which are least associated with basic survival, valuing political action and speech over the work of making concrete things, and work over the unending labour of filling basic needs; it is not unreasonable to suggest that her system is founded in, and seeks to further entrench, class privilege. ${ }^{44}$ However, this critique ignores the degree to which Arendt emphasises the mutual interdependence of labour, work, and action; while intellectual and political endeavours are the ideal pursuit of humans in the world, there is no escape from the necessary labour of survival and work of building the world in the first place. $^{45}$

There are, for my purposes, two important points to take from Arendt: first, that world-building is a necessarily human endeavour, and a constant process, rather than something accomplished by divine fiat once upon a time. Second, 
the production of art objects plays an essential role in the world-building endeavour:

If the animal laborans needs the help of homo faber to ease his labor and remove his pain, and if mortals need his help to erect a home on earth, acting and speaking men need the help of homo faber in his highest capacity, that is, the help of the artist, of poets and historiographers, of monument-builders or writers, because without them the only product of their activity, the story they enact and tell, would not survive at all. ${ }^{46}$

For Arendt, art plays an essential role in the construction of the human, in the transformation of the creatures' dwelling space from earth to world, and in ensuring the relative permanence of that transformation. Art makes us human-but in so doing, it also reflects our humanity. It is a vessel which contains, into which the artist breathes, the essential qualities that differentiate human from mere creature-it is, in theological language, an image. In terms which Arendt herself seems likely to have rejected, art is an image of the image, a secondary image, a graven image. In Arendt's schema, it is the human, rather than the divine, creator which produces the image and imbues it with life, and in so doing the creator realises their own humanity. ${ }^{47}$

\section{CREATION}

In spite of their differences, then, both Benjamin and Arendt construct a relationship between the work of art and human being that is closely analogous to the relationship between human and divine expressed in the Theology of Image: the irreducible uniqueness of a work of art is a window into the nature of humanity, just as Theology of Image treats the irreducible uniqueness of a human being as a window into the nature of the divine. Understood via Benjamin and Arendt, then, any work of artistic production, figurative, abstract, or non-objective, is unavoidably a transgression of the second commandment - but it is also an unavoidable, and perhaps even necessary, transgression. By this, I mean that the capacity for transgressiveness, the urge to create art-not just material objects, nor decorative representations of the world as it is, but rather the drive to originality, the urge to create something wholly new - this urge is a direct inheritance from the creator in whose image humanity was made.

But-returning to the problem alluded to in my earlier discussion of Martland-what does this actually mean for art, for the producers thereof, and for the critics and theologians who comment upon it? Am I not just reinscribing the outdated narrative of Jewish iconoclasm so effectively 
dispatched by Kalman Bland at the beginning of this century? Am I not relegating Jewish material culture to the realm of decorative arts and crafts, forever divorced from any reflective or transformative potential, and similarly revealing Jewish thought to have little to contribute to a theology of art beyond restriction? Admittedly, the chain of reasoning I have followed could very well lead to just that point. I resist this conclusion, however, on two grounds. First, the art/craft dichotomy is itself an over-simplification. I myself am a trained - though no longer practising-studio artist, as well as a student, collector, and practitioner of craft; I have a long experience of creating, viewing, and analysing works of both art and craft. There is nothing new under the sun; I have seen (and, to my chagrin, produced) plenty of 'art' which would not fit the criteria of a wholly new creation, and certainly would not constitute the mutually transformative engagement between maker and object that Martland proposes. Indeed, a skilled critic could argue for the derivative nature of nearly any work. By contrast, I have seen (though, again to my chagrin, not produced) many examples of functional or decorative objects which reveal startling originality and a deep engagement on the part of their maker. My intent here is not to perpetuate what is, in my view, a largely false dichotomy in relation to Jewish material culture, but rather to disrupt and problematise it. If idolatry is in the mind and hand of the maker rather than the eye of the beholder, then attempting to categorise artistic output as idolatrous or reverent, forbidden or safe for theological reflection, is a futile endeavour.

Second, the historical narrative that restricts Jewish material production to the realm of craft reveals an incomplete understanding of the complex nature of Jewish discourse about issues connected to idolatry. ${ }^{48}$ In his article entitled 'Attitudes Towards Christianity in the Halakah', Louis Jacobs traces the development of halakic positions on the manufacture, possession, and use of devotional objects belonging to other religions; the Christian cross is a paradigmatic example. ${ }^{49}$ Jacobs suggests that exposure to Christianity, which combined iconism with a clearly delineated monotheism, led Rabbis of the post-Talmudic period to construct a halakic category of objects and actions which are forbidden to Jews as idolatrous, but permitted to Gentiles as nonidolatrous. ${ }^{50}$ This in-between category complicated the previously clearly delineated categories of idolatrous and permitted objects, leading to distinctions based on use, rather than form-for example, Jacobs cites several rulings, most notably from R. Isserles and R. Joseph Saul Nathanson of Lemberg, that a Jew is permitted to wear a cross as an ornament, provided that it has never been used for purposes of worship. ${ }^{51}$

Jacobs's narrative of the historical evolution of halakic thought on the issue ignores that there are even similar passages in the Talmud-for example the exchange between Proclos and R. Gamaliel regarding the latter's use of 'the 
Bath of Aphrodite'. Gamaliel offers Proclos several reasons that his presence in the bath is not a violation of the commandments against idolatry:

Nobody says the bath was made as an adornment for Aphrodite; but he says, [the
statue of] Aphrodite was made as an adornment for the bath. Another reason is, if
you were given a large sum of money, you would not enter the presence of a
statue reverenced by you while you were nude or had experienced seminal
emission, nor would you urinate before it. But this stands by a sewer and all
people urinate before it. It is only stated, their gods-i.e. what is treated as a deity
is prohibited, what is not treated as a deity is permitted.

Gamaliel's criteria for distinguishing between decorative object and idol are twofold: first, there is the question of intent-Aphrodite is an adornment for the bath, and not the other way around; second, and moreover, there is the question of actual use, and the statue in question is demonstrably not used as an object of worship. While there is no evidence in this passage of the third category of objects forbidden-for-Jews-but-permitted-to-Gentiles that Jacobs sees arising from the medieval period, the use criterion is clearly developed. One might even argue that the intent criterion could be subsumed within the use criterion, as the artist or craftsperson who creates an object intending that it should represent, or function as, divinity also participates in the recognition of that object as divine.

In this case, R. Isserle's ruling permitting a cross as ornament becomes impractical, unless the cross is manufactured by a (presumably nonChristian) craftsperson who sees in the symbol no representation of divinity; otherwise, the ornament is tainted by its association with idolatry from the moment of its manufacture. R. Nathanson's ruling, which specifically refers to civic medals in the shape of a cross, has, in my view, more practical weight, as it is more likely that the civic symbolism of the medal would overpower the religious symbolism of its shape than that a Christian might manufacture a cross that lacks such additional symbolic associations, and also not consider it a representation of the divinity of Christ. Even in this case, however, one must hold as highly improbable that the conditions of the object's manufacture, the degree of reverence in which it was or was not held by its creator, would be known to the person who ultimately possesses it. To relocate the property of being an idol from an object's form to its conditions of manufacture, as I have done in this article and as I argue the earlier halakhic tradition supports, is to move that property beyond the realm of the visible (though, certainly, there are forms of use which bring that property back into focus).

The ultimate result of this close engagement with a broad range of Jewish sources is to expand the potential for religious engagement with art, while heightening individual responsibility for the activities of artists and critics. Any 
form of material production risks slipping into idolatry, as the drive to originality becomes, either as a form of self- or object-worship on the part of the maker, or maker-worship on the part of the viewer or critic, the production's controlling value. This is the danger - though by no means certain - of the theory of art proposed by Martland. But any form of material production can also avoid this slippage, by maintaining focus on the production as an image of creation, rather than creation itself.

This is, as I warned at the beginning, only a very preliminary attempt at addressing Jantzen's call for a theology which permits itself to be destabilised (and reshaped) by serious engagement with alterity. The shift in focus from art as the object of a viewer's gaze to art as the process of imagination and concretization opens up a multitude of new ways forward for theology of art. In the first instance, a focus on the act of making, rather than viewing something which has already been made, provides strong incentive for theologians to move beyond the historical canon of great works, with all of its gendered and ethnic problematics; it may prompt an engagement with living artists that, in turn, brings newer understandings of the religious and spiritual more readily within the space of theological consideration. ${ }^{53}$ It may encourage reflexivity and an increased attentiveness to the standpoint of the researcher-although I do not wish to suggest that a theology that attends to art as a process of making requires the theologian to pick up their own paintbrush; Arendt's more expansive view of making as an essential sphere of human activity, not limited to the plastic arts, should not be forgotten: we are all, in some way, homo faber; we are all participants in the work of creation.

\section{REFERENCES}

1 Literature and Theology I6 (2002) 427-49.

2 Jantzen, pp. 427-8. I should note that Jantzen is interested specifically in a theology of beauty, where I am interested in a theology of art, which is not quite the same thing-but the two concerns have significantly more commonalities than differences.

3 Not wishing to turn the current article into an extensive review, I note examples only from the past two years - the same scope of time covered in Jantzen's article-which, taken together, suggest that the discipline in general has not gone very far in confronting the limitation critiqued therein: T. Hart, Making Good: Creation, Creativity and Artistry (Waco, TX: Baylor University Press, 20I4); J.M.
Watkins, Creativity as Sacrifice: Toward a Theological Model for Creativity in the Arts (Minneapolis, MN: Fortress Press, 2015); S.J. Wright, Dogmatic Aesthetics: A Theology of Beauty in Dialogue with Robert W. Jenson (Minneapolis, MN: Fortress Press, 20I4).

${ }^{4}$ H. Rosenberg, 'Is There a Jewish Art?', Commentary Magazine, text of a lecture given at the New York Jewish Museum, first published I July I966. https://www.commentarymagazine.com/ article/is-there-a-jewish-art/, accessed I 8 December 20I4.

5 The most popular example of this is the fictional Asher Lev, in C. Potok, My Name Is Asher Lev (London: 
Penguin, 1974), but there are ample examples chronicled in scholarly writing as well, e.g. S. Baskind, "Midrash and the Jewish American Experience in Jack Levine's Planning Solomon's Temple', Ars Judaica 3 (2007) 73-90 at 78; J. Breslin, Mark Rothko: A Biography (Chicago, IL: University of Chicago Press, I993); R. Jacoby, Picture Imperfect: Utopian Thought for an Anti-Utopian Age (New York: Columbia University Press, 2007), p. I I6; C. Roth, 'Jewish Art and Artists Before Emancipation', in C. Roth (ed.), Jewish Art: An Illustrated History (London: W.H. Allen, I96I), p. 522; A. Werner, 'Jewish Artists and the Age of Emancipation', in C. Roth (ed.), Jewish Art: An Illustrated History (London: W.H. Allen, I96I), p. 539.

${ }^{6}$ See, e.g. M. Baigell, American Artists, Jewish Images (Syracuse, NY: Syracuse University Press, 2006), pp. 2-4; S. Baskind and L. Silver, Jewish Art: A Modern History (Clerkenwell: Reaktion, 20II); C.M. Soussloff (ed.), Jewish Identity in Modern Art History (Berkeley, CA: University of California Press, I999).

7 Admittedly, many of the more recent studies address the second commandment issue primarily to dismiss it: see, e.g. Z. Braiterman, The Shape of Revelation: Aesthetics and Modern Jewish Thought (Stanford, CA: Stanford University Press, 2007), pp. xxv-xxx; M. Olin, The Nation without Art: Examining Modern Discourses on Jewish Art (Lincoln, NE: University of Nebraska Press, 200I), p. 5; M. Raphael, Judaism and the Visual Image: $A$ Jewish Theology of Art (London: Continuum, 2009), pp. I9-42; A. Rosen, Imagining Jewish Art: Encounters with the Masters in Chagall, Guston, and Kitaj (London: Legenda, 2009), pp. 2-3.

8 A.-J. Levine, The Misunderstood Jew: The Church and the Scandal of the Jewish Jesus (San Francisco, CA: HarperCollins 2006), p. I2; see also the contributions of $\mathrm{R}$. Cohen, J.W.H. van Wijk-Bos, M. Godin, G. Haaland, and D. Weissman, in Part III of J. Svartvik and J. Wirén (eds), Religious Stereotyping and Interreligious Relations (New York: Palgrave Macmillan, 2013), pp. I37-9I. Of course, what I identify as 'a hermeneutics of contrast' is a considerably kinder, gentler exponent of the adversos iudaeos tradition, from which I believe most current Christian theologians would wish to believe themselves to be separated-and the extent to which this belief may or may not be true in general is an issue well outside the boundaries of the present article; suffice it to say that in the particular case of the visual arts any lingering tendency towards the adversos tradition is supported by the history and theology that Jews themselves have authored. As most scholars writing on theology and art are not primarily (or even secondarily) invested in language issues which more properly belong to theology of religions, I have coined, and will utilise, the far milder term.

9 There is one recent volume which has attempted an engagement with Jewish texts: J.A. Goroncy (ed.), Tikkun Olam/To Mend the World: A Confluence of Theology and the Arts (Eugene, OR: Pickwick Publications, 20I4), but this engagement is almost entirely restricted to post-Holocaust texts, which form the basis of the book's leitmotif of a broken world into which art and Christian theology intervene to reveal God's redemptive grace.

${ }^{10}$ Raphael, Judaism and the Visual Image, pp. $45-6$.

11 S.A. Handelman, The Slayers of Moses: The Emergence of Rabbinic Interpretation in Modern Literary Theory (Albany, NY: SUNY Press, I982), p. IOI.

12 Oxford English Dictionary, s.v. image (n.)

13 Genesis I:27. My translation here departs from the literal and grammatical Hebrew in favour of sensible and accurate expression in English, which does not have inbuilt grammatical gender as Hebrew doesin this passage is taken to refer to humanity, both male and female, rather 
than to specifically to 'the man' (Rashi's rather fanciful explanation of this passage- seemingly derived from Plato's Symposium-aside); I also avoid the use of gendered pronouns to refer to God. Avoiding pronouns necessitates some rearrangement in the order-most obviously, the second and third clauses are switched around, as the order they appear in Hebrew ('filled with the image of God, male and female, God created them') may give the tautologous impression that God is filled with God's own image, which, while likely true, is rather beside the point (thanks to Max Goldman for pointing this out). Finally, I have rendered the first two inברא as it appears in the Hebrew) as 'filled', which implies the Lurianic image of God's emanation flooding into the void at the moment of creation. The third instance of the root ברא is translated as the more standard 'created'; a more skilful translator would be able to carry the image of filling through the entire passage without causing confusion or disrupting the flow of the passage.

14 A. Green, Radical Judaism: Rethinking God and Tradition (New Haven, CT: Yale University Press, 20I0).

15 The universalism in this statement is not accidental; see Mishnah Sanhedrin 4:5.

16 Cf. W. Benjamin, 'The Work of Art in the Age of Mechanical Reproduction', in H. Arendt (ed.), Illuminations, trans. $\mathrm{H}$. Zohn (New York: Schocken Books, I969), pp. 217-52: 'In principle a work of art has always been reproducible. Manmade artifacts could always be imitated by men. Replicas were made by pupils in practice of their craft, by masters for diffusing their works, and, finally, by third parties in the pursuit of gain' (Illuminations, p. 212).

D. Blumenthal, Facing the Abusing God: A Theology of Protest (Louisville, KY: Westminster/John Knox, I993), pp. 6-8.

18 E.g. Leviticus I9:2 and II:44.

19 Blumenthal, p. 8.

20 This reading of the Theology of Image owes a great deal to J. Miles, God: $A$
Biography (New York: Vintage Books, I996).

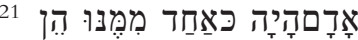

22 'Therefore' is used in the Twenty-First Century King James Version, American Standard Version, Amplified Bible, Darby Translation, English Standard Version, King James Version, New American Standard Bible, New King James Version, and the New Revised Standard Version; 'So' appears in the Contemporary English Version, Holman Christian Standard Bible, The Message, New Century Version, New International Version, New International Reader's Version, New Living Translation, and Today's New International Version.

23 The idolatrous/reverent distinction is drawn by Raphael in Judaism and the Visual Image (see especially pp. 37-42); she introduces it in an effort to undermine overly simplistic assumptions of Jewish aniconism, and bring into question more recent, but equally simplistic, portrayals of Jewish art as an exponent of nebulously defined Jewish cultural tendencies. For more on the second commandment as focussed on imitation and restriction, see A. Vincent, 'Imitation and Finitude: Towards a Jewish Theology of Making', in C. Welz (ed.), The Ethics of In-Visibility: Imago Dei, Memory, and the Prohibition of Images (Tübingen: Mohr Siebeck, 20I5), pp. 87-100.

24 The earliest date I am aware of art historians assigning to the notion of art with which I am about to engage is $\mathrm{I} 573$, when Paolo Veronese appeared before the Inquisition to defend the artistic choices he made in composing his painting, Feast at the House of Levi (originally titled The Last Supper) - but see below regarding the linguistic evolution of the word.

25 Oxford English Dictionary, s.v. 'art', s.v. 'craft'.

26 OED notes that this use did not appear in English dictionaries until the nineteenth century; "before then, it seems to have been used chiefly by painters and writers on painting'. 
27 P. Greenhalgh, 'The History of Craft', in P. Dormer (ed.), The Culture of Craft (Manchester: Manchester University Press, 1997), p. 26.

28 C.B. Fethe, 'Craft and Art: A Phenomenological Distinction', British Journal of Aesthetics I7 (I977) I3 I.

29 See Fethe, pp. I29-3 I.

30 T.R. Martland, 'Art and Craft: The Distinction', British Journal of Aesthetics I4 (I974) 236.

31 One must assume that Martland was preoccupied with the aesthetic effect of alliteration and neglected to note that Pygmalion and the King of Cyprus are the same person, and the statue with which he fell in love came to be named Galatea; nevertheless, the myth which he references remains recognisable, and the trope of made objects coming to life is clearly discernible.

32 See, especially, N. Adams, G. Pattison and G. Ward (eds), The Oxford Handbook of Theology \& Modern European Thought (Oxford: Oxford University Press, 20I3).

33 For Benjamin, 'political' and 'cultic' are opposite values, the latter depending on a system of centralised authority and the former on decentralised power structures controlled by the masses.

${ }^{34}$ Benjamin, p. $2 \mathrm{I} 7$.

35 Ibid., p. 2 I 8.

${ }^{36}$ Ibid., p. 2 I 4.

37 C.W. Haxthausen, 'Reproduction/ Repetition: Walter Benjamin/Carl Einstein', October 107 (2004) 50.

38 Benjamin, pp. 2I4-I6; pp. 234-5.

39 H. Arendt, The Human Condition (Chicago, IL: University of Chicago Press, I998), p. I67.

40 Ibid., p. I69.

41 Ibid., p. I68.

42 Ibid., pp. I73-4: 'In order to be what the world is always meant to be, a home for men during their life on earth, the human artifice must be a place fit for action and speech, for activities not only entirely useless for the necessities of life but of an entirely different nature from the manifold activities of fabrication by which the world itself and all things in it are produced.'

43 R. Sennett, The Craftsman (Westminster: Penguin Books, 2009).

44 Sennett's critique begins from a reasonable impulse, but is problematic-it confuses animal laborans with homo faber, and then proceeds to defend work not as a good in itself, but as intrinsically connected to what Arendt frames as the higher activity of thought and action, leaving his claim of 'rescuing' animal laborans open to question.

45 Arendt, p. 228.

46 Ibid., p. I73.

47 Miles suggest that this structure of relationship between creator and creation, in which the mirroring action of the creation is necessary for the creator's realisation of their own potential, is implicit in the narrative structure of the Hebrew Bible.

48 The essential sources for understanding the general shape of this discourse are M. Halbertal and A. Margalit, Idolatry, trans. N. Goldblum (Cambridge, MA: Harvard University Press, 1992), L. Kochan, Beyond the Graven Image: A Jewish View (New York: New York University Press, I998), and E.R. Wolfson, Through a Speculum That Shines: Vision and Imagination in Medieval Jewish Mysticism (Princeton, NJ: Princeton University Press, 1994). See also S. Pearce (ed.), The Image and Its Prohibition in Jewish Antiquity (Oxford: Journal of Jewish Studies, 2013).

49 L. Jacobs, 'Attitudes Towards Christianity in the Halakah', in Judaism and Theology: Essays on the Jewish Religion (London: Valentine Mitchell, 2005), pp. I02-I6.

50 Ibid., p. I08.

51 Ibid., p. I09, citing R. Isserles Yoreh $D e^{\prime} A h$ I4I:I and R. Joseph Saul Nathanson of Lemberg Shoel u-Meshiv Vol. I, Part 3, No. I7I.

52 BT Avodah Zarah 44b.

53 Of course, this suggestion depends, perhaps optimistically, on artists not being singled out on the basis of their holding doctrinal standpoints in sympathy with the researcher. 